\title{
Late Triassic and Early Jurassic palaeogeographic evolution and depositional cycles of the Western Tethys Iberian platform system (Eastern Spain)
}

\author{
Juan J. Gómez ${ }^{\mathrm{a}, \mathrm{T}}$, Antonio Goy \\ ${ }^{a}$ Dpto. de Estratigrafú and UEI de Correlaciones Estratigráficas, Facultad de Ciencias Geológicas (UCM) and \\ Instituto de Geología Económica (CSIC-UCM), Ciudad Universitaria, 28040 Madrid, Spain \\ ${ }^{\mathrm{b}}$ Dpto. and UEI de Paleontología y UEI de Paleontología, Facultad de Ciencias Geológicas (UCM) and \\ Instituto de Geología Económica (CSIC-UCM), Ciudad Universitaria, 28040 Madrid, Spain
}

\begin{abstract}
Deposition of Upper Triassic and Lower Jurassic sediments on the Iberian platform system took place in a post-rift intraplate basin which formed part of the western Tethys shelf. Nevertheless, there is evidence for the tensional reactivation of a network of faults with associated magmatic activity. Early Jurassic palaeogeographic reconstructions, based on over 70 sections and 9 oil wells, reveal the presence of a series of highs and lows (depocentres). Two main highs, referred to as the El Maestrazgo High, in the east, and the La Mancha High, in the west, where condensed sections were deposited, were mainly controlled by syndepositional faults. The main depocentres were situated between these two highs areas, in a northwest trending belt in the central, northern and southern areas. Despite partial fault control, development of some Early Jurassic depocentres appears to be mainly controlled by thermal contraction of the lithosphere following Triassic main rifting pulse. The Upper Triassic-Lower Jurassic succession of the Iberian platform system was deposited during four transgressive and regressive cycles of 12 to 6 My duration. The lowermost cycle LJ-1 started in late Norian and lasted until the Sinemurian. The second cycle LJ-2 started in the Sinemurian and ended in the Pliensbachian (Davoei Zone), and can be subdivided into two minor cycles LJ2-1 and LJ2-2. The cycle LJ-3 started with an extensive upper Pliensbachian (Davoei Zone) transgression, whereas the top of its regressive cycle is dated to the Toarcian (Variablilis Zone). Within cycle LJ-3, three cycles can be distinguished. Maximum deepening was reached during the Bifrons Zone and active volcanism took place along the Teruel and Caudiel faults. The transgressive phase of the cycle LJ-4 started in the Thouarsense Zone and extended up to the Insigne Zone; its regressive phase developed during the upper Toarcian (Pseudoradiosa and Aalensis Zones) and part of the Aalenian (Opalinum and Murchisonae Zones). This cycle can be subdivided in two minor cycles, with their transgressive peaks occurring during the Insigne Zone, and the Aalensis Zone respectively. Palaeogeographically this corresponds with the expansion of the marginal carbonate platforms over hemipelagic deposits. The top of the cycle corresponds to a major unconformity with regional emersion during the Aalenian Murchisonae Zone.
\end{abstract}

Keywords: Upper Triassic; Lower Jurassic; carbonate platforms; palaeogeographic maps; rifting; cyclostratigraphy

T Corresponding author. Fax: +34 913944808.

E-mail addresses: jgomez@geo.ucm.es (J.J. Gómez), angoy@geo.ucm.es (A. Goy). 


\section{Introduction}

Early Jurassic palaeogeographic reconstruction have resulted in progressively more detailed palaeogeographic maps of the Western Tethys (Ziegler, 1982, 1990; Bradshaw et al., 1992; Bassoullet et al., 1993; Decourt et al., 1993; Thierry, 2000a,b; Ziegler et al., 2001; Stampfli et al., 2001) and of different platforms in Spain (Capote et al., 1982; Gómez, 1985a,b, 1991; Vera, 2001; Aurell et al., 2002, 2003;
Gómez and Goy, 2004). Some of these maps show the presence of a system of epicontinental platforms delimited by extensional faults (Fig. 1), which formed part of a complex array of blocks, in the interference zone of the Artic-North Atlantic and Western Tethys rift systems (Ziegler, 1990; Ziegler et al., 2001; Stampfli et al., 2001).

The Iberian Range, a NW trending fold- and thrustbelt in eastern Spain, represented a significant element of the western margin of the peri-Tehyan basin (Fig. 2,

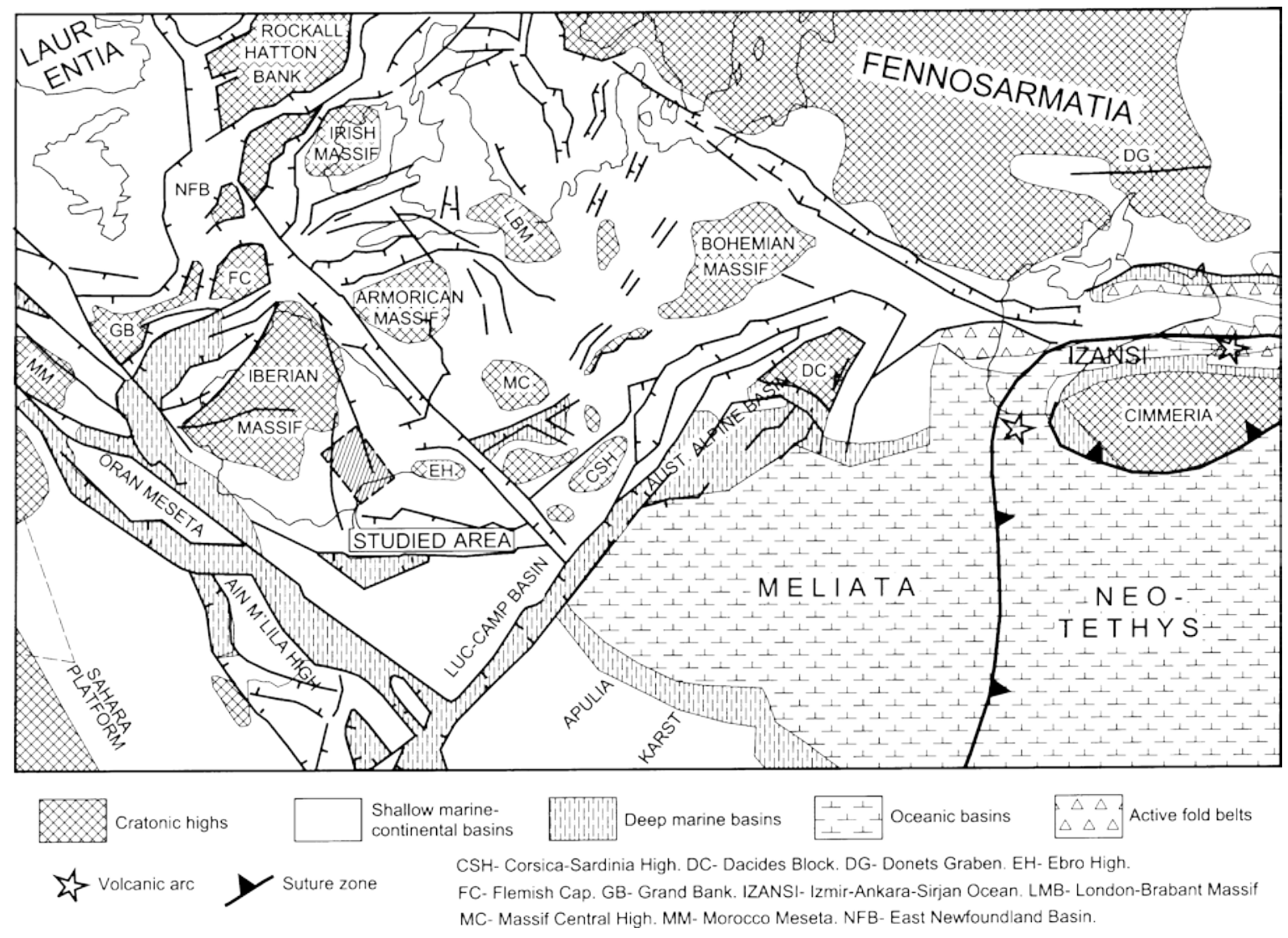

Fig. 1. Palaeogeographical map of the Tethys area for the upper part of the Early Jurassic (Ziegler, 1990; Stampfli et al., 2001; modified). The Iberian platform system occupied the westernmost area of the peri-Tethyan domain. 


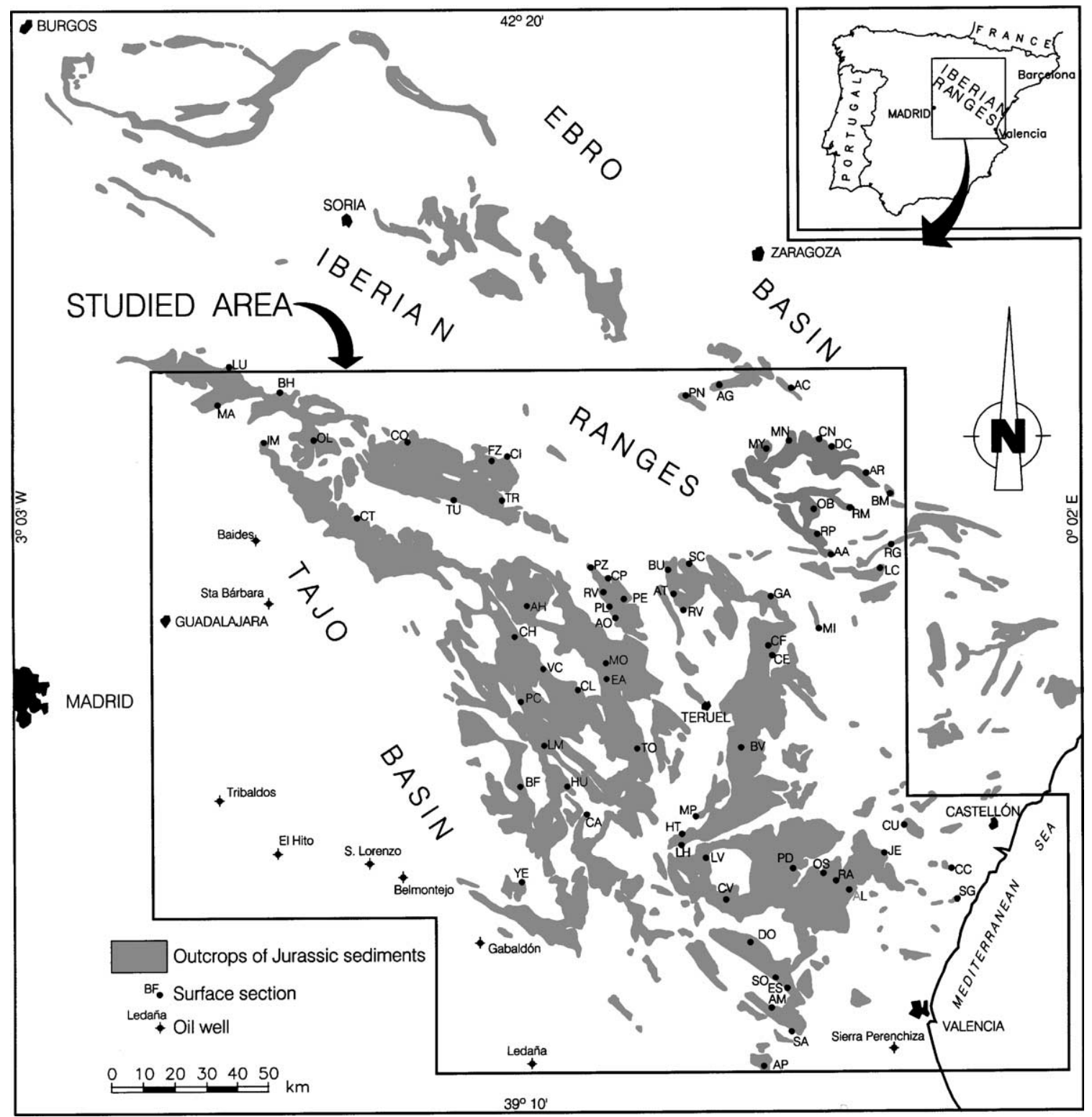

Fig. 2. Outcrops of Jurassic deposits in the Iberian Range (shown in gray), location of the studied sections and wells, and boundaries of the studied area. Abbreviations of sections: AA: Arroyo de los Anchos, AC: Almonacid de Cuba, AG: Aguilón, AH: Alustante-Horihuela, AL: Alcublas, AM: Alto de Malen, AO: Almohaja, AP: Arroyo Picastre, AR: Ariño, AT: Aguatón, BF: Barranco de la Fuente, BH: Barahona, BM: Barranco del Moro, BU: Bueña, BV: Barranco del Val, CA: Campillos Paravientos, CC: Chilches, CE: Cedrillas, CF: Casterlfrío, CH: Checa, CI: Cimballa, CL: Calomarde, CN: Cascán, CO: Chaorna, CP: Casas de Parla, CT: Cortes de Tajuña, CU: Caudiel, CV: Chelva, DC: Decantadero, DO: Domeño, EA: Etrambasaguas, ES: Ermita de Sot, FZ: Fuentelsaz, GA: Galve, HT: Hoz del Turia, HU: Huérguina, IM: Imón, JE: Jérica, LC: La Cañadilla, LH: Las Higueruelas, LM: Laguna del Marquesado, LU: Lumias, LV: Las Ventosillas, MA: Miedes de Atienza MI: Masía de Ivernal, MN: Moneva, MO: Mompedroso, MP: Masía del Perdulo, MY: Moyuela, OB: Obón, OL: Olmedillas, OS: Oset, PC: Puerto del Cubillo, PD: Peñas de Dios, PE: Peracense, PL: Piedra Larga, PN: Paniza, PZ: Pozuel, RA: Rambla de Alcublas, RG: Río Guadalopillo, RM: Río Martín, RP: Río Palomar, RS: Rambla del Salto, RV: Rambla de Valdetorre, SA: Siete Aguas, SC: San Cristóbal, SG: Sagunto, SO: Sot de Chera, TO: Tormón, TR: Tortuera, TU: Turmiel, VC: Villar del Cobo, YE: Yémeda. 
Salas et al., 2001). During the Late Triassic and Early Jurassic this area comprised a system of shallow platforms that developed on the progressively submerging Iberian block. Intracratonic extensional faulting controlled the palaeogeographic evolution of these platforms and in some regions syndepositional tectonic activity strongly affected fluctuations in depositional water depth.

The study of more than 70 surface sections, with excellent outcrop conditions, and 9 oil wells (Fig. 2) permits a detailed reconstruction of the thickness distribution of the different lithostratigraphic units of the Upper Triassic-Lower Jurassic succession in this area and subdivision into transgressive-regressive facies cycles. These cycles are partially correlative with the cycles recognized by Hesselbo and Jenkins (1993), de Graciansky et al. (1998), Jacquin and de
Graciansky (1998), Gianolla and Jacquin (1998), and Hallam (2001) for Western Europe.

\section{Transgressiveand regressive cycles of the Late Triassic and Early J urassic on the Iberian platform system}

On the Iberian platform, the Late Triassic and Early Jurassic cycle is represented by an up to $550 \mathrm{~m}$ thick succession of shallow marine carbonates with interbedded marls and evaporites (Fig. 3). The succession has been subdivided into several lithostratigraphic units (Goy et al., 1976; Gómez and Goy, 1979, 1981, 1998, 1999; Gómez et al., 2003), and many biostratigraphical studies have dated most of the Lower Jurassic sediments at a zone- to horizon-scale (Goy,

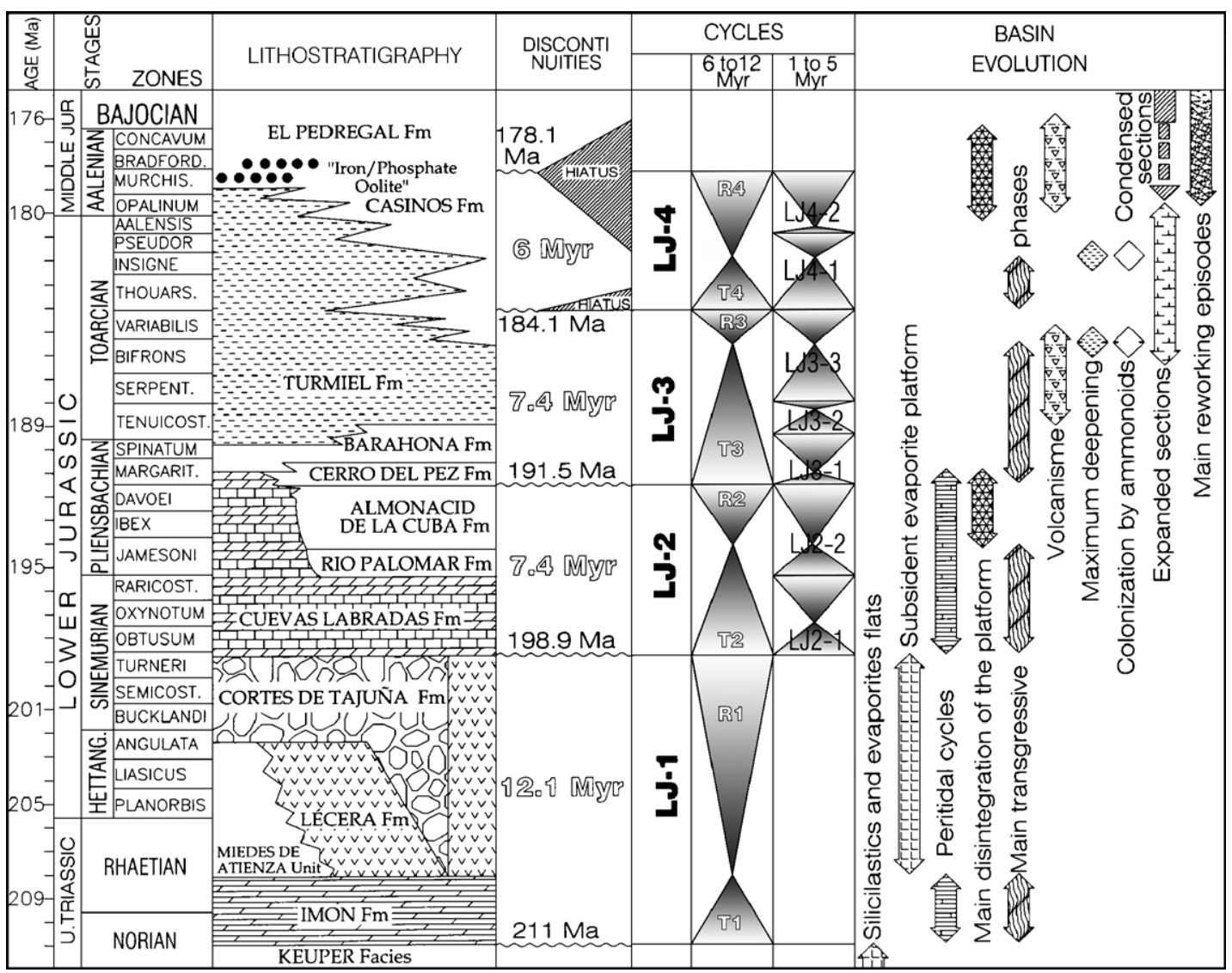

Fig. 3. Cycles of the Upper Triassic and Lower Jurassic deposits in the Iberian platform system. The position of the major unconformities and main events in the evolution of the Iberian platform system are indicated. 
1974; Gó mez, 1979; Ureta, 1985; Comas-Rengifo, 1985; Fernández-Ló pez, 1985). Some attempts towards the definition of cycles have also been undertaken (Yébenes et al., 1988; Salas and Casas, 1993; Gómez and Goy, 1997, 2004; Bordonaba and Aurell, 2001, 2002; Aurell et al., 2002, 2003), with special emphasis on the cycles in the Toarcian (Gómez and Goy, 2000).

In the present study, lithostratigraphic and biostratigraphic criteria as well as palaeogeographic, sedimentologic, taphonomic and palaeoecologic data, were used to distinguish the Late Triassic and Early Jurassic depositional cycles. Four transgressive and regressive facies cycles (LJ-1 to LJ-4) with a duration varying between 6 and 12 My are recognized. In cycles LJ-2 to LJ-4, seven cycles with duration between 1 and 5 My can be documented (Fig. 3). Cycles of a duration of 6 to 12 My are bounded by unconformities which are commonly associated with condensed sections and/or a hiatus. The dating of the lower cycles is based on palynomorphs (Gómez and Goy, 1998; Barró n and Goy, 1994; Barró n et al., 2001), and available regional data (Goy and Márquez-Aliaga, 1998; Arnal et al., 2002). Ammonoid biostratigraphy permit precise timing for the Pliensbachian, Toarcian and Aalenian (Goy, 1974; ComasRengifo, 1985; Ureta, 1985; Ferná ndez-Ló pez, 1985). In our study we refer to the geochronological scales of Grandstein et al. (1995) and de Graciansky et al. (1998).

\section{Cycle LJ -1}

This cycle is considered to start in the late Norian and extends into the Sinemurian (Gianolla and Jacquin, 1998; Jacquin and de Graciansky, 1998; Hardenbol et al., 1998). The transgressive phase (T1) involved flooding of the extensive evaporitic playa flat, corresponding to the bKeuperQ facies, and the development of a wide shallow marine to peritidal carbonate platform which covered much of the Iberian platform. The transgressive facies is represented by carbonates of the Imón Formation (Fig. 3). It is made up of shallowing-upwards sequences (Gómez, 1991), consisting of three units. The lower unit composed of dolomitic grainstone bars with cross-bedding (locally beach facies). The intermedi- ate unit composed of microcrystalline dolomites, occasionally with ripples, bioclastic rills interpreted as tempestites, and bioturbation. The upper unit characterized by algae laminities, broken laminae, fenestral and evaporite mouldic porosity and enterolithic folds (Gómez, 1979, 1991; Gómez and Goy, 1998). The thickness of this transgressive unit varies between 14 and $40 \mathrm{~m}$. Available biostratigraphical data favors a Norian-Rhaetian age for the Imón Formation, based on the presence, in the northwestern portion of the area, of bivalves known from the lower part of the Rhaetavicula contorta beds of the Alps (Goy and Márquez-Aliaga, 1998). Moreover, a late Norian (latest Alaunian-Sevatian) age for the lower part of the equivalent unit in the Pyrenees and Catalonia, supports a Norian age for the lower part of the transgressive Imón Formation, as suggested on the basis of foraminifera (Márquez et al., 1994; Arnal et al., 2002).

The regressive phase (R1) is marked by the deposition of a thick pile of evaporites with minor interbedded dolomites, corresponding to the Lécera Formation (Fig. 3, Gómez and Goy, 1998, 1999). This unit is composed of massive to banded gypsum and anhydrites occasionally with ripples and enterolithic folds. The dolomites commonly show algal laminites and occasionally ripples, tepee structures and algal boundstone facies. This unit is mainly preserved in the subsurface in the adjacent Tajo and Ebro Cenozoic basins (Castillo-Herrador, 1974; Morillo Velarde and Meléndez Hevia, 1979; Jurado, 1990; Gó mez and Goy, 1998). The regressive evaporitic unit exclusively outcrops in the Lécera area (Decantadero section, Fig. 2), in the northeastern portion of the studied area (Rios et al., 1981; Gó mez, 1991). However, it can be traced to the northeast on seismic lines and in wells. The TriassicJurassic transition probably occurs within this evaporitic unit (Pérez-Ló pez et al., 1996) which is more than $250 \mathrm{~m}$ thick in the subsurface. In most outcrops, evaporites are dissolved and the unit is represented by the massive and porous dolomitic collapse breccias and equivalent crystalline carbonates of the Cortes de Tajuñ a Formation, which normally is thinner than $100 \mathrm{~m}$ (Fig. 3). Palynomorphs collected in the lower portion of this unit indicate a Hettangian age (Barrón and Goy, 1994; Gómez and Goy, 1998, 1999). In the northwestern 
portion of the studied area, attached to the Iberian Massif, a marly unit (Miedes de Atienza unit) probably representing distal fan-delta facies, is believed to be in part the time-equivalent of the evaporitic unit.

\section{Cycle LJ -2}

A lower Sinemurian age is assumed for the basal part of the second cycle, as dated by ammonoids in the open marine facies of northern Spain (Suárez Vega, 1974; Braga et al., 1988), which correlates with the cycles defined in central Europe, dated by ammonoids in the Paris Basin and in the United Kingdom (de Graciansky et al., 1998). The top of cycle LJ-2 has been dated in the Iberian Range on the basis of ammonites to the Pliensbachian, Davoei Zone (Comas-Rengifo, 1985; Comas-Rengifo et al., 1999; Gómez et al., 2003).

The transgressive phase (T2) is represented by the development of a new carbonate platform dominated by peritidal to shallow marine environments corresponding to the Cuevas Labradas Formation (Fig. 3). The top of the regressive phase of the cycle LJ-2, is commonly indicated by a remarkable hardground surface.

Palaeogeographic reconstruction of the Cuevas Labradas Formation shows the total or partial absence of the Jurassic sediments in the western portion of the studied area due to non-deposition or Cretaceous to Recent erosion (Fig. 4). Data on Jurassic sediments are not available from the central-northern area, where Paleozoic rocks are exposed or the Cenozoic

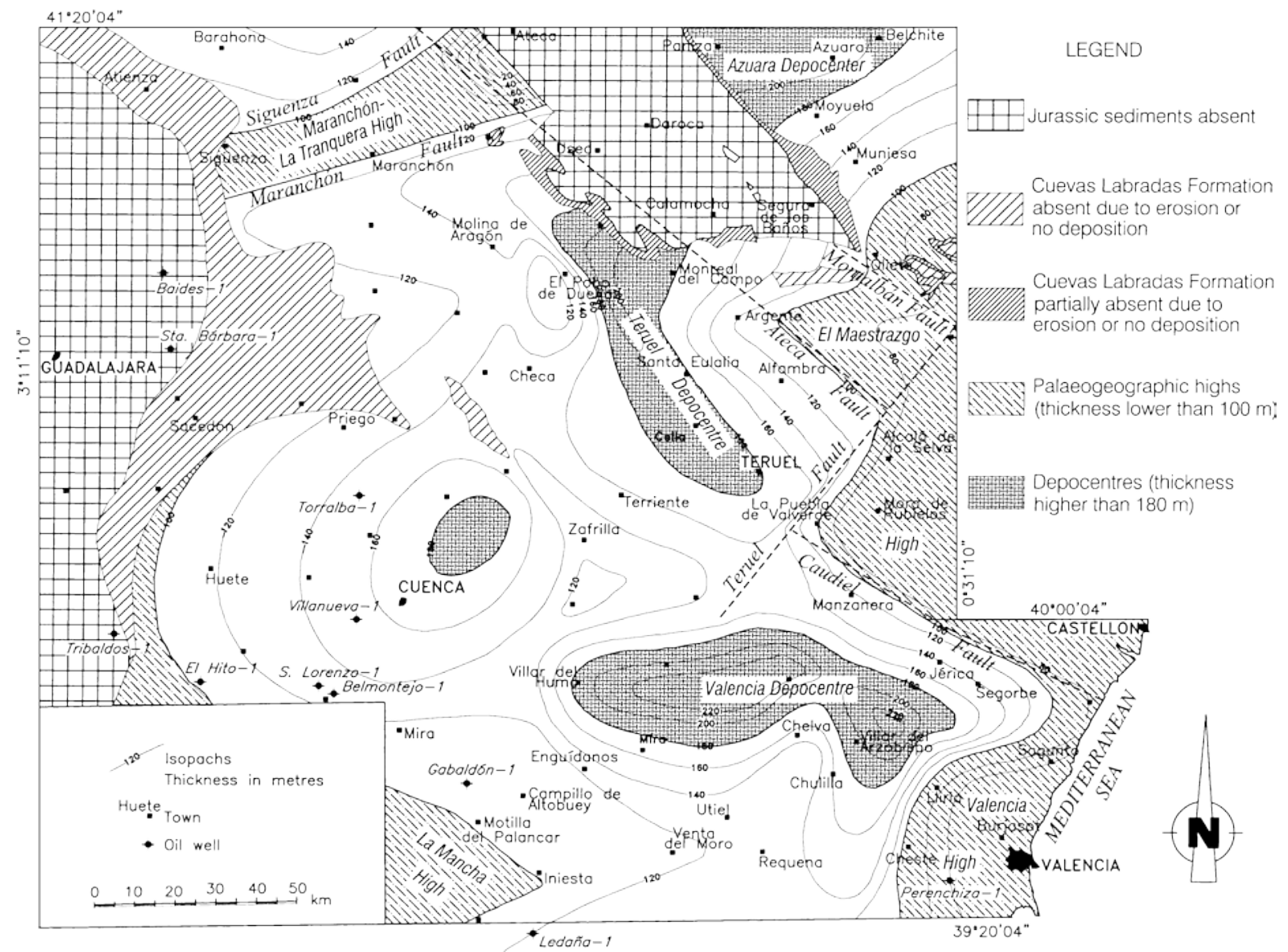

Fig. 4. Thickness distribution and palaeogeographic elements of the Cuevas Labradas Formation (early Sinemurian to Pliensbachian). 
cover does not allow observation of Jurassic sediments. The thickness distribution reflects the presence of the El Maestrazgo and Valencia highs in the east, the Maranchón-La Tranquera High in the north, and the La Mancha High to the west, close to the emergent Iberian Massif. A grid of NE and NW-trending extensional normal faults controls the distribution of the highs (Fig. 4). Successions thinner than $100 \mathrm{~m}$ occur on the highs, whereas expanded sections, over $180 \mathrm{~m}$ thick and consisting mainly of peritidal carbonates, were accumulated in the depocentres. In the northeastern part of the area, movements along the extensional Montalbán Fault caused subsidence of hanging wall blocks located to the northeast of the fault, and the generation of enough accommodation space as to allow better development of the two cycles LJ2-1 and LJ2-2.

\subsection{Cycle LJ2-1}

This cycle is represented in most of the area by the peritidal facies of the Cuevas Labradas Formation (Fig. 3). The top of the cycle can be dated as upper Sinemurian, Raricostatum Zone. The Cuevas Labradas Formation is composed of peritidal sequences with a lowermost unit composed of subtidal marls, commonly absent, overlain by cross-bedded oolitic grainstone, with, mudstone to wackestone limestones which may contain bioclastic rills, ripples, lenticular bedding and bioturbation, followed by limestones or dolomites with microbial laminities. The uppermost unit is composed of carbonates with fenestral porosity, mud-cracks, evaporites mouldic porosity, enterolithic folds, chicken-wire and tepee structures, and calcretes.

\subsection{Cycle LJ2-2}

This cycle is recorded in the block northeast of the Montalban Fault better than in the block located southwest of this fault (Fig. 4). The transgressive interval is represented by the muddy subtidal platform carbonate facies of the Rio Palomar Formation (Gó mez, 1991; Gó mez et al., 2003) that forms shallowing-upwards sequences of lime mudstone to wackestone containing bioclastic rills with interbedded marls and marly limestones. Ammonoids and brachiopods allow dating of these sediments as lower Pliensbachian Jamesoni Zone (Sequeiros et al., 1978;
Comas-Rengifo, 1985; Comas-Rengifo et al., 1999). Peak transgression was reached during deposition of the Almonacid de la Cuba Formation which consist of ammonite- and brachiopod-bearing alternating marls and lime mudstone. This unit, which is organized into sets of shallowing-upwards and deepening-upwards sequences, was deposited on a restricted external platform that was partially isolated from open marine environments during the early part of the Pliensbachian Jamesoni, Ibex and Davoei Zones.

During the accumulation of these units, syndepositional extensional tectonics controlled break-up of the Early Jurassic platform into a system of smaller platforms, which continued to evolve during the Early and Middle Jurassic. As a result of these movements, the external platform environments extended up to the Catalan Coastal Range, located to the northeast of the studied area (Comas-Rengifo et al., 1998).

\section{Cycle LJ -3}

On the Iberian platform, the cycle LJ-3 started during the upper Pliensbachian Davoei Zone and extended up to the upper Toarcian Variabilis Zone, Vitiosa Subzone. This 7.4 My long cycle was markedly asymmetrical. The transgressive phase (T3) developed during the early Pliensbachian to middle Toarcian time span, whereas regressive phase developed mainly during a part of the Bifrons and the Variabilis Zones. Peak transgression occurred during the middle Toarcian Bifrons Zone, which also represents the maximum transgression of the cycles developed during Late Triassic and Early Jurassic (Gómez and Goy, 2000). The upper boundary of the cycle LJ-3 is marked by an unconformity that is associated with condensed sections and a hiatus. The upper portion of the Variabilis Zone as well as a part or the whole Thouarsense Zone can be missing (Gó mez and Goy, 2000). Within cycle LJ-3, three 1-5 My cycles, LJ3-1, LJ3-2 and LJ3-3 can be recognized.

\subsection{Cycle LJ3-1}

This cycle is composed of a transgressive phase, mainly represented by the Cerro del Pez Formation and a regressive part mainly represented by the 
Barahona Formation (Fig. 3). The ammonite- and brachiopod-bearing marls of the Cerro del Pez Formation contain interbedded lime mudstones with minor wackestones and occasional skeletal packstones to grainstones organized in shallowing and deepeningupward sequences. The maximum flooding surface occurred within the upper Pliensbachian Margaritatus Zone (Comas-Rengifo et al., 1999). From a palaeogeographic point of view, this unit reflects an extensive flooding of the platform, except for the fault controlled El Maestrazgo-Valencia High and the La Mancha High, where it is not present (Fig. 5), and where shallow carbonate platform conditions persisted. However, small grabens allowed for local deposition of this unit like west of Cheste on the El Maestrazgo-Valencia High.
The regressive part of the LJ3-1 cycle is represented by a return to the platform carbonate deposition, represented by the bioclastic limestones of the Barahona Formation (Fig. 3). This unit consists mainly of lime wackestone to packstone, occasionally mudstone and grainstone, skeletal (Gryphaea) limestones, and minor interbedded marls. In the eastern portion of the area, the unit contains volcanic tuffs (Gautier, 1968, 1974), distributed along some of the more active extensional faults. This unit is organized into aggradational shallowing-upwards sequences that were deposited on a shallow platform that was frequently influenced by storms (Gómez, 1991). Locally, wavedominated beach environments associated with bioclastic bars are recorded. This unit yielded ammonoids of the upper Pliensbachian Margaritatus and Spinatum

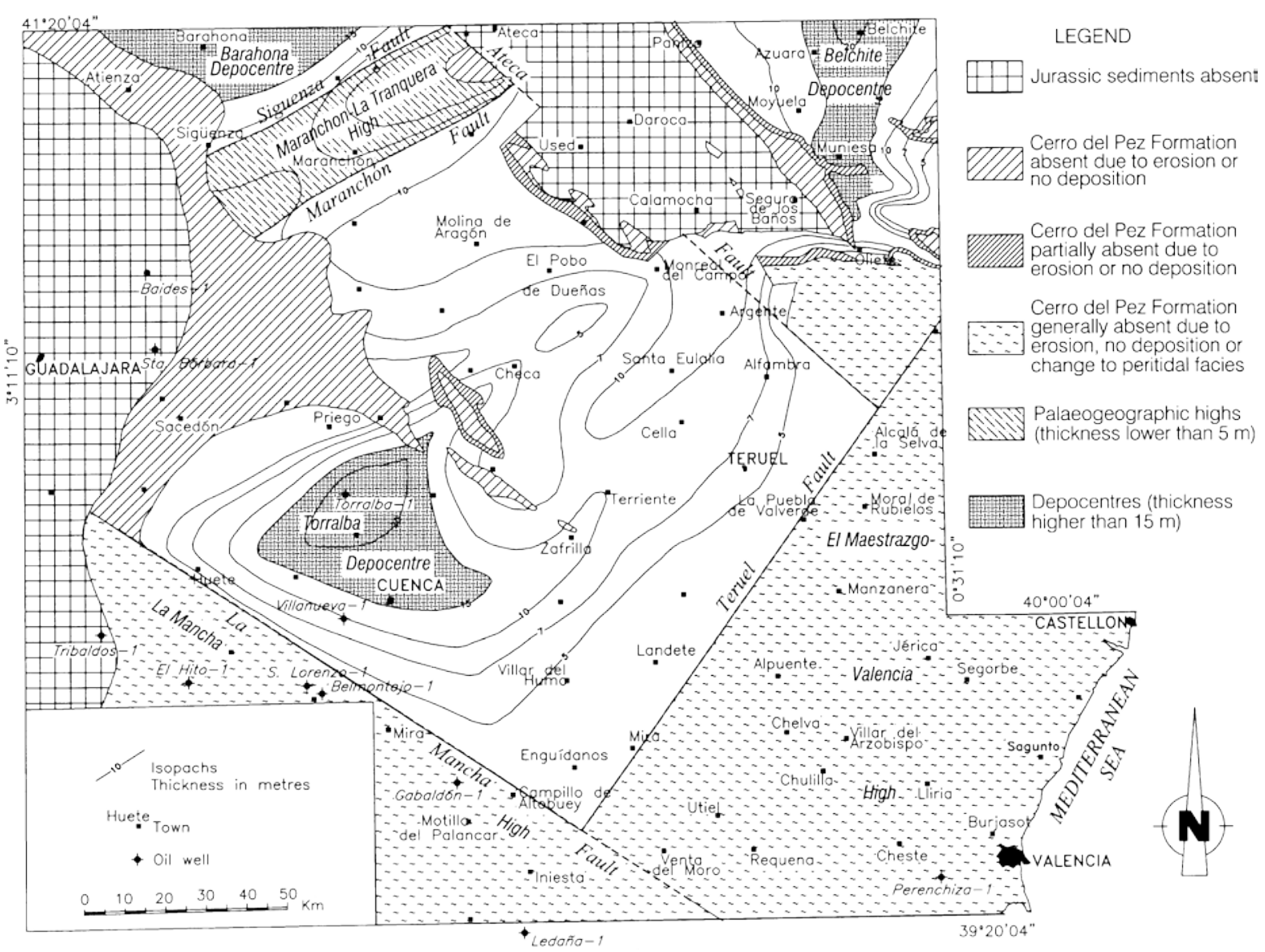

Fig. 5. Thickness distribution and palaeogeographic elements of the Cerro del Pez Formation (Pliensbachian, part of the Davoei and the Margaritatus Zones). 
Zones (Comas-Rengifo, 1985). However, owing to synsedimentary tectonics (Goy et al., 1997), the top of the unit is diachronous at a stage-scale, as shown in the central portion of the southwestern branch of the Iberia Ranges, where its upper boundary has been dated to the lower Toarcian Tenuicostatum Zone (Goy, 1974; Comas-Rengifo, 1985). The Barahona Formation was deposited in shallower waters than the previous unit, but due to normal faulting and subsequent widening of the basin, oversteps the depositional limits of the Cerro del Pez Formation. The thickness distribution of this unit is dominated by the presence of two faultcontrolled depocentres located to the north of Teruel and Valencia respectively (Fig. 6), and two high areas delineated by the $10 \mathrm{~m}$ isopach. The El Maestrazgo High is bounded by the Caudiel Fault, and the Cuenca High is delimited to the south by the La Mancha Fault, which confined the southward transgressions during the subsequent Pliensbachian-Toarcian LJ3-2 cycle. As a consequence, a large area located southwest of the La Mancha Fault remained restricted to peri-tidal conditions during Early Jurassic.

\subsection{Cycle LJ3-2}

On the Iberian platform system, this cycle can be subdivided into two minor sub-cycles, which can be traced into the Cantabrian and Asturias basins of northern Spain (Gómez and Goy, 2000). The LJ3-2 cycle started with a generalized transgressive event during the early part of Tenuicostatum Zone (early Toarcian). Maximum deepening was reached in the lower portion of the Semicelatum Subzone, and coincided with an anoxic event, that is represented

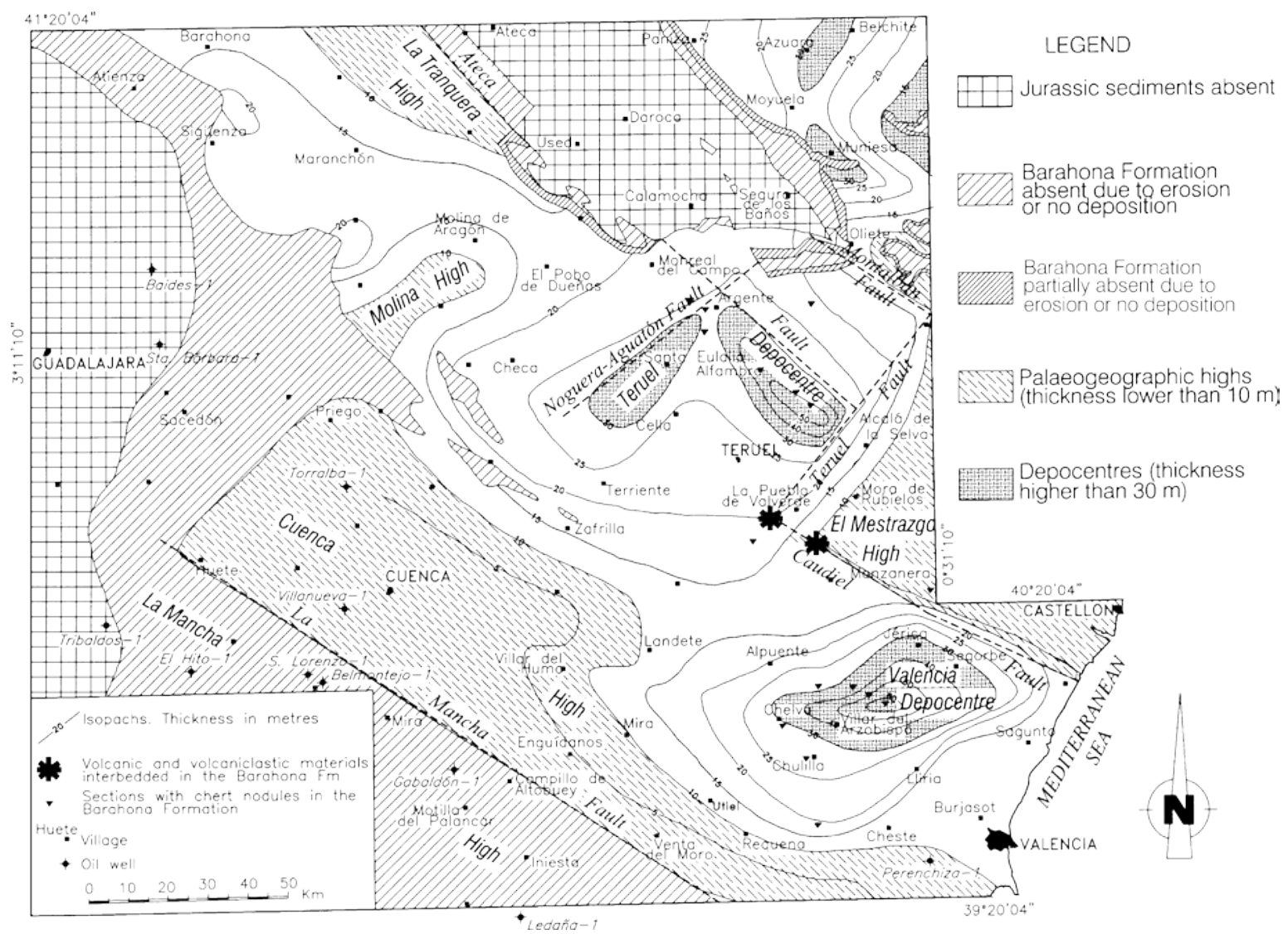

Fig. 6. Thickness distribution and palaeogeographic elements of the Barahona Formation (Pliensbachian, part of the Margaritatus and the Spinatim Zones, locally up to lower Toarcian Tenuicostatum Zone). 


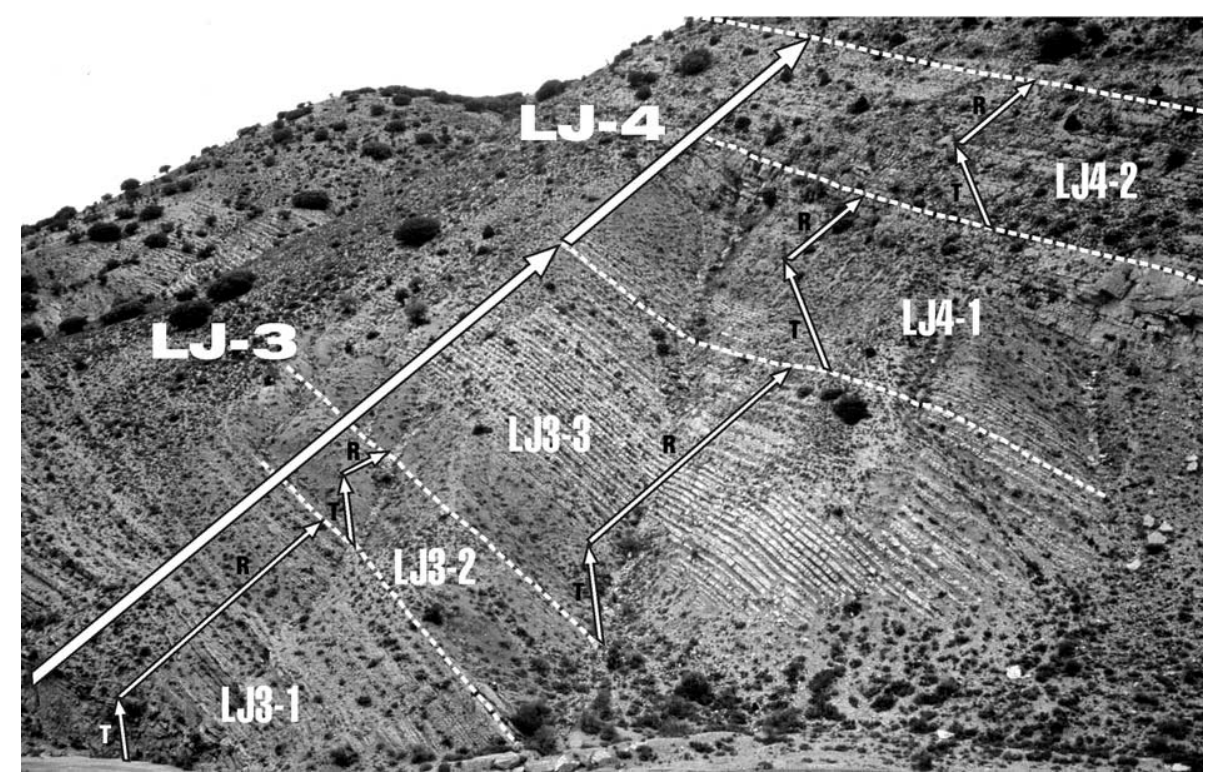

Fig. 7. Outcrop of the Rambla del Salto section, showing lithological expression of cycles LJ-3 and LJ-4, as well as cycles LJ3-1 to LJ4-2. Arrows pointing to the left represent the transgressive part and arrows pointing to the right the regressive part of the cycle.

in the study area by a decrease in the diversity of benthic faunas (Goy et al., 1997). However, no blackshale facies were developed. The regressive part of the lower sub-cycle occurred near the boundary between the Tenuicostatum and the Serpentinus Zones. The second sub-cycle developed up to the lower part of the Serpentinus Zone. As observed on the Iberian platform system, the Toarcian transgression is not represented by a continuous simple deepening episode, but by several pulses (Gómez and Goy, 2000). This transgressive event resulted in flooding of the platform, and the establishment of external platform environments, facilitating the transport of ammonite shells by drift into most of the area of our studies.

The facies are dominated by the alternation of marls and mudstone carbonates of the Turmiel Formation (Figs. 3 and 7) which are organized into sets of deepening and shallowing-upwards sequences (Gómez and Goy, 2000). In the areas where pelagic conditions were reached at the Pliensbachian-Toarcian boundary, an excellent ammonoid-based biozonation of this transition has been made in the northeastern portion of the studied area (Mouterde, 1971; Goy et al., 1997; Comas-Rengifo et al., 1996, 1999). The main depocentres of this unit, partially controlled by the Noguera-Aguatón Fault (Fernández-
López and Gómez, 1990a), are located in the Monreal and Azuara areas (Fig. 8). The El Maestrazgo and the Valencia Highs were partially bounded by the Teruel and Caudiel Faults, which are marked by the occurrence of quite active, mainly pyroclastic, volcanism. As in previous intervals, the La Mancha Fault bounded the extension of the external platform facies to the southwest, where internal to peritidal environments persisted.

\subsection{Cycle LJ3-3}

The transgressive phase of this cycle commenced in the lower Toarcian Serpentinus Zone and extended up to the Bifrons Zone, when the maximum Early Jurassic transgression was reached. The top of the regressive interval is dated by ammonoids as uppermost Variabilis Zone (upper Toarcian). The upper boundary of this cycle coincides with a regional discontinuity, associated with condensed sections and a hiatus, which commonly affects the lower portion of the Thouarsense Zone (Gómez and Goy, 2000).

The transgressive interval is represented by a set of deepening-upward sequences composed of rhythms of marls and carbonates on which layers of marls are thickening upwards. During the Bifrons Biochron, 


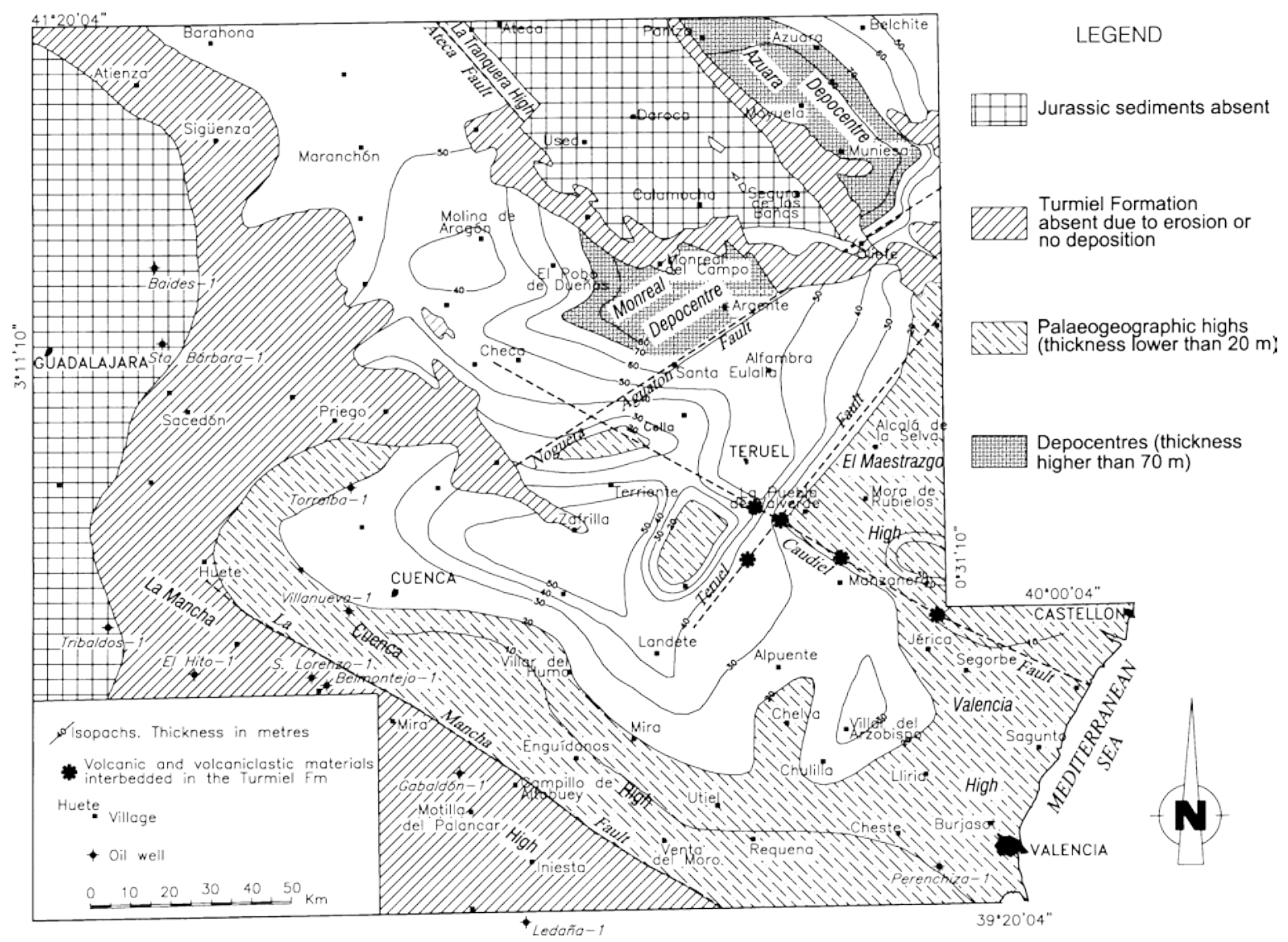

Fig. 8. Thickness distribution and palaeogeographic elements of the Turmiel Formation (Toarcian, locally upper Pliensbachian and Aalenian).

general flooding of the platforms resulted for the first time in the colonization of the studied part of the Iberian platform system by ammonoids. The regressive part of this cycle is characterized by a set of shallowing-upward sequences in which carbonates thicken upwards with respect to marls (Fig. 7). The general palaeogeographic setting of this cycle, mainly represented by the Turmiel Formation, is shown in Fig. 8. In the southern part of the area, the regressive phase marks the onset of progradation of a marginal carbonate platform, corresponding to the Casinos Formation, across the marly Turmiel Formation.

\section{Cycle LJ -4}

This cycle is asymmetrical. The transgressive phase (T4) starts at the Thouarsense Zone and extended up into the upper portion of the Insigne Zone (upper Toarcian). The regressive interval (R4) developed during the upper part of the Insigne Zone, and the Pseudoradiosa and the Aalensis Zones of the upper Toarcian, and the Opalium and Murchisonae Zones of the Aalenian. The peak transgression occurred in the upper Toarcian Insigne Zone. The upper boundary of the cycle coincides with a major unconformity that is associated with condensed sections and a hiatus. This cycle can be subdivided into two cycles, LJ4-1 and LJ4-2 (Fig. 7).

\subsection{Cycle LJ4-1}

The transgressive phase and peak transgression of this cycle coincide with that of the LJ-4 cycle. The transgressive interval is mainly represented by a set of deepening upward sequences of the alternating 
marls and limestones of the Turmiel Formation in the northern part of the study area. Renewed deepening of the platform gave rise to a further episode of local colonization of the platform by ammonoids. The regressive phase developed during the Insigne and Pseudoradiosa Biochrons, and controlled the progressive progradation of surrounding carbonate platforms represented by the Casinos Formation (Fig. 3).

During deposition of this unit, activity along northeast and northwest trending fault system controlled sedimentation on El Maestrazgo High (Fig. 9) with the Caudiel Fault acting as feeder system for the extrusion of volcaniclastics, flows and epiclastic tuffs, forming mounds which locally conditioned carbonate deposition (Gautier, 1968; Ortí and Sanfeliú, 1971; Gómez et al., 1976; Gómez, 1979; Ortí and Vaquer, 1980; Fernández-López et al., 1985; Martínez González et al., 1996, 1997).

\subsection{Cycle LJ4-2}

A short transgressive interval developed in the Pseudoradiosa and Aalensis Zones, with a peak transgression recorded in the Aalensis Zone (Fernández-López, 1997; Fernández-López et al., 1998 a,b). The regressive interval extended up into the Murchisonae Zone of the Aalenian. The cycle is mainly represented by the Casinos Formation, which is composed of mudstone to wackestone, occasionally bioclastic wackestone to packstone limestones, that may contain interbedded marls. In the upper portion of the unit, the top of the shallowing upwards sequences are commonly marked by the presence of ferruginous/phosphatic hardgrounds, as well as indications for emersion and karstification (Fendler, 1979; Fernández-Ló pez and Gó mez, 1990b). Associated with reworked deposits, which contain ferruginous and/or phosphatic ooids, bioclasts and lithoclasts,

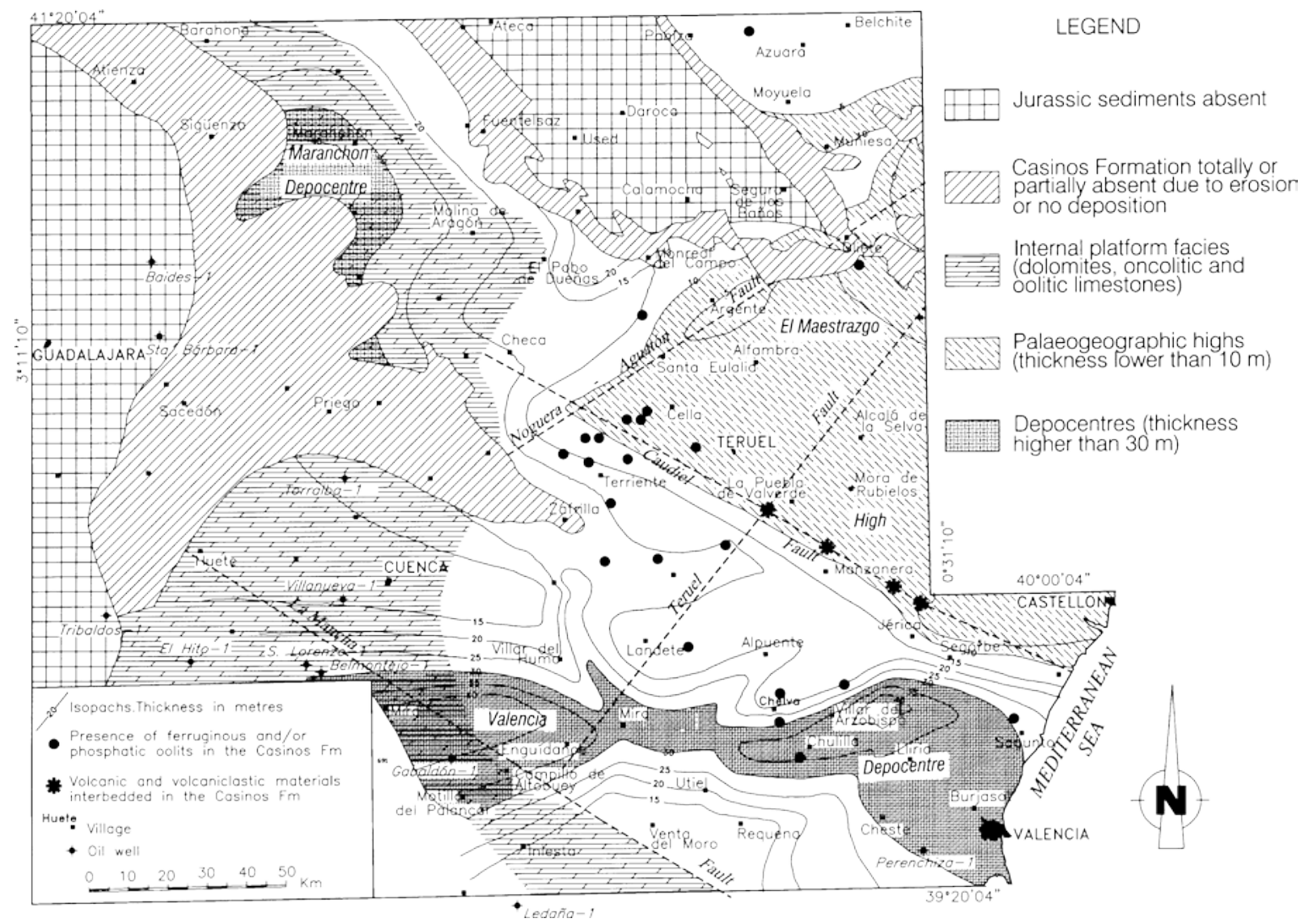

Fig. 9. Thickness distribution and palaeogeographic elements of the Casinos Formation (Toarcian-Aalenian). 
fossils which have been exhumed and displaced before final burial are also found (Fernández-López, 1991). These are condensed sections, related to stratigraphic discontinuities and associated hiatus (Fernández-Ló pez, 1985, 1997; Fernández-López and Gómez, 1990a,b; Gómez and Fernández-López, 1994, 2004). In fault controlled half-grabens, as in the Fuentelsaz section, pelagic facies persist through the Toarcian-Aalenian boundary. This section has been selected by the IUGS as the Global boundary Stratotype Section and Point (GSSP) for the Toarcian-Aalenian boundary (Cresta et al., 2001). In these sub-basins, excellent ammonoid-bearing sections, including NW European and Mediterranean faunas are recorded.

\section{Discussion and conclusions}

On the Iberian platform system, a transgressiveregressive cycle is recognized during the Norianmiddle Aalenian time span, that can be correlated with the Ligurian cycle of de Graciansky et al. (1998) and Jacquin and de Graciansky (1998). The cycle consists of four subcycles with a duration of 6-12 My. This time interval fits with the bsecond order cyclic nonperiodic sequenceQ category (7-12 My) proposed by Guillocheau (1995). The facies cycles LJ-1, LJ-2 and LJ-3 reflect progressive flooding of the westernmost peri-Tethyan platforms, represented by the eastern part of the Iberian block. During the successive LJ-1 to LJ3 cycles, the transgressive intervals became progressively longer and inundated increasingly larger areas, whilst the corresponding regressive intervals became shorter. The maximum deepening of the platform was reached in the Bifrons Biochron, and was followed by a general shallowing during the regressive LJ-4 cycle.

The cycles LJ-2 to LJ-4 are subdivided into seven minor cycles, each with a duration of 1-5 My, which falls into the bfirst order of cyclic nonperiodic sequencesQ (0.6-5 Ma) of Guillocheau (1995), and close to the bsequence cyclesQ (0.5-3 Ma) of Jacquin and de Graciansky (1998). The revised cycle-chart represented here for the Upper Triassic and Lower Jurassic sequences of the Iberian platform system shows some differences respect to previous cycle-charts proposed for this area (Fig. 10, Aurell et al., 2003).
Comparison with cycles defined in other areas of Europe, like in the Lusitanian Basin (Duarte et al., 2001), the Boreal an Tethyan areas (de Graciansky et al., 1998; Gianolla and Jacquin, 1998), the United Kingdom (Hesselbo and Jenkins, 1993) and the Sequence Chronostratigraphic Chart proposed by Haq et al. (1988), summarized in Fig. 10, shows some strong lines of correlation.

Details of the cycle LJ-1 are quite difficult to unravel on the Iberian platform system, as its regressive facies is represented by a thick evaporitic succession which has been dissolved in outcrops. However, it is possible that the Jurassic cycle started during the Norian, as has been pointed out by de Graciansky et al. (1998) and Gianolla and Jacquin (1998) for the Boreal and Tethyan domains. This is in agreement with the age of transgressive deposits assigned to this cycle in the Pyrenees (Márquez et al., 1994). The proposed Rhaetian age for the onset of the regressive interval on the Iberian platform system is reflected on similar position of the UAB1 unit of Haq et al. (1988).

The Sinemurian transgression is a point of general agreement, marking the beginning of relative sealevel rise in the United Kingdom (Hesselbo and Jenkins, 1993) and in the Boreal region (de Graciansky et al., 1998). It also coincides with the boundary between cycles 3.1 and 3.2 of Haq et al. (1988). The lower Pliensbachian peak transgression (Jamesoni Zone) appears to coincide on the different platforms (Hallam, 2001). Assuming the possible limitations shown by Catuneanu et al. (1998), the early Pliensbachian transgression has been recorded on the Iberian platform system, as well as in the Boreal domain. The upper Pliensbachian (Davoei and Margaritatus Zones) change from a regressive to a transgressive subcycle is another major point of general agreement, except for the Tethyan area. However, the peak transgression recorded in the middle Toarcian (Bifrons Zone), appears to coincide in many areas. Except for Portugal and the UK, this is a main candidate to be considered as one of the most widespread peak transgressions of the Mesozoic, probably due to a pronounced eustatic rise in sea-level. Taphonic populations of ammonoids of the Bifrons Zone are indicative for the colonization of the Iberian platform during this interval. Other episodes of local colonization, indicatives of trans- 

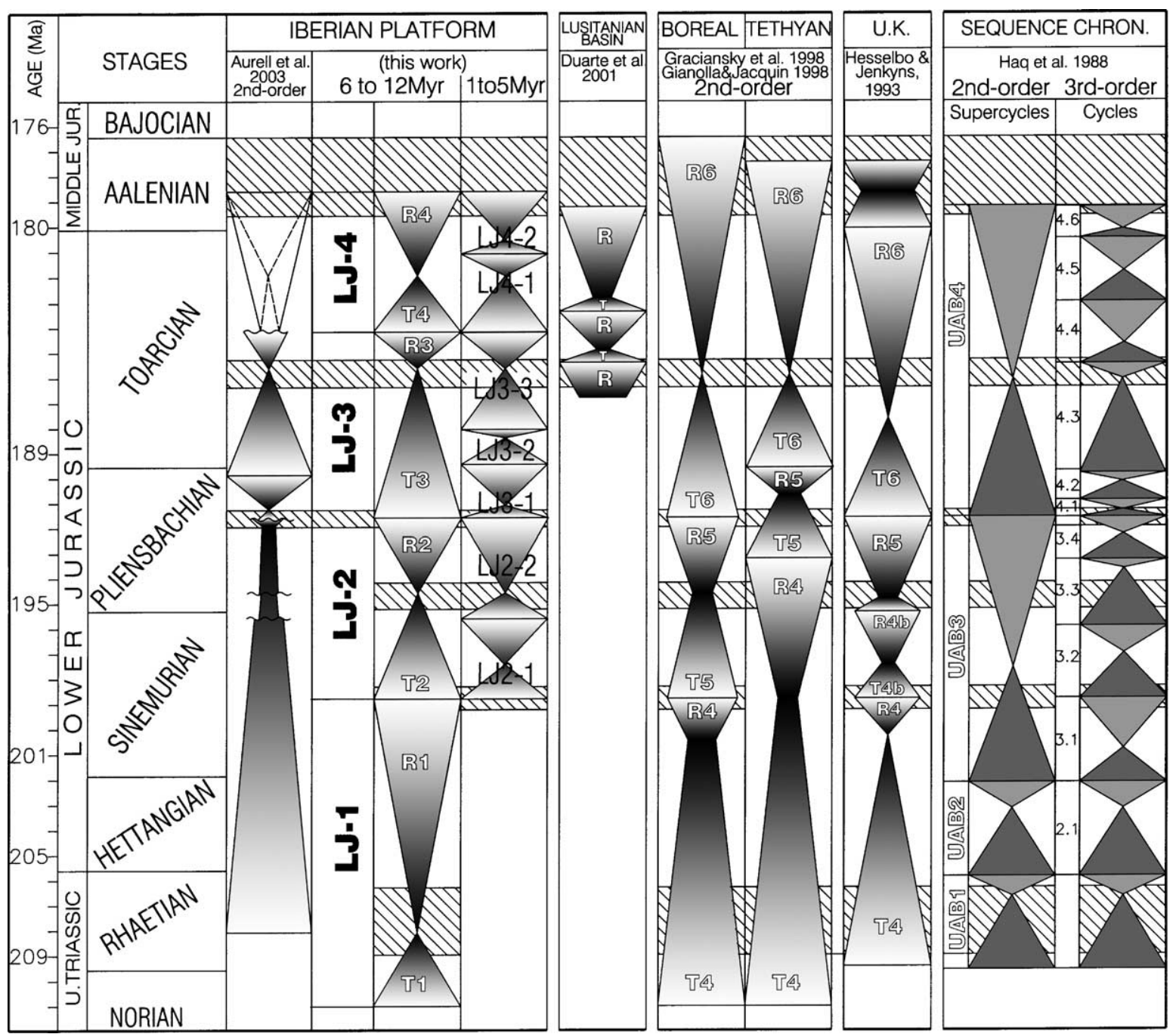

Fig. 10. Correlation chart of cycles recognized in the Iberian platform system and other platforms of Europe as well as Sequence Chronostratigraphy.

gressive peaks, are recorded in the Insigne and Aalensis Zones. However, the early Toarcian anoxic event (Jenkyns and Clayton, 1986, 1997; Jenkyns, 1988; Jiménez et al., 1996; Harris and Little, 1999) is recorded on the Iberian platform system in the Tenuicostatum Zone, Semicelatum Subzone, by an impoverishment of the benthic biota, and not as organic black-shale facies.

The remarkable regressive interval that occurred during the Aalenian (Hallam, 2001) is probably related to the opening of the Atlantic. However, comparison of the different areas reflects a consid- erable diachroneity for the peak regression. Although an Aalenian general sea-level fall appears to be valid for the European Plate, the high degree of tectonic fragmentation is held responsible for the observed strong diachroneity in the onset of the regressive cycle in the different basins.

The study of more than 70 surface sections, under excellent outcrop conditions, and 9 oil wells allowed a detailed reconstruction of the thickness distribution for the different units of the Upper Triassic and Lower Jurassic sequences of the Iberian Platform. The maps show areas where Lower Jurassic sedi- 
ments have been preserved from erosion and areas were information on sediments of the respective time interval is not available due to erosion or nondeposition (Figs. 4-6 and 8,9). On the basis of the thickness distribution of the different units, a series of highs and depocentres could be delineated. Two main highs, the El Maestrazgo High located to the east, and the La Mancha High located to the west, are recognized. The El Maestrazgo High was mainly controlled by the Caudiel, Teruel, Ateca and Montalbán faults, tracing an extensional dogleg pattern (Harding and Lowell, 1979). The La Mancha High was controlled since Pliensbachian times by the La Mancha Fault that restricted the advance of successive Early Jurassic transgressions to the southwest. As a consequence, peritidal facies persisted southwest of this palaeogeographic element for most of Early Jurassic. During deposition of some units (i.e. Turmiel Formation) the two highs were joined in the southeast through the area of Valencia. On those highs, condensed sections were deposited, whilst expanded sections are recorded in the depocentres areas. Volcanic activity along northwest and northeast trending faults, controlling highs and depocentres, was significant during some time intervals (e.g. Toarcian), indicating that fault activity during the Early Jurassic cannot be considered as negligible, as suggested by Salas et al. (2001). Some depocentres were at least spatially and temporally partly controlled by faulting. Yet the regional development of accommodation spaces appears to have been dominantly controlled by thermal subsidence, with subsidence centres located in the central-northern area, represented in the successive intervals by the Teruel, Belchite and Monreal-Azuara depocentres, and the Valencia Depocentre located to the south.

During Norian to Sinemurian times the Iberian platform was a quite continuous palaeogeographic unit that started disintegration during the early Pliensbachian. Extensional tectonics resulted in the differentiation of a platform system, formed by an external restricted platform facies northeast of the Montalbán Fault, in downthrown blocks, and the continuity of peritidal platform environments southwest of this fault. The late Pliensbachian transgression LJ3-1 was only recorded in the fault bounded graben located in the central portion of the area, which was located between elevated areas, where shallow platform carbonate environments persisted. A peak in faulting activity was reached during the Toarcian, coupled with igneous activity, and culminated during the early-middle Aalenian when tectonic differentiation of the platform led to maximum environment instability during which widespread condensed sections and diastems developed. This Toarcian and Aalenian extensional tectonic peak is related to the opening of the Atlantic-Alpine-Tethys rift system, in which rifting of Western and Central Europe, with related magmatic activity in the Iberian platform system, was achieved during the Bajocian (Ziegler et al., 2001; Stampfli et al., 2001). Pelagic facies persisted only in local areas, such as in Fuentelsaz (Figs. 2 and 9), the type locality of the Toarcian-Aalenian boundary, and excellent sections including NW European and Mediterranean ammonoid faunas were recorded.

\section{Acknowledgements}

This work has been funded by project BTE 20011924 of the Spanish Ministerio de Ciencia y Tecnología. We wish to thank Dr. Peter A. Ziegler, Dr. F. Surlyk and Dr. M. Aurell for valuable advice, comments and constructive criticism; this paper was very much improved as a result of their review.

\section{References}

Arnal, I., Calvet, F., Márquez-Aliaga, L., Solé de Porta, N., 2002. La plataforma carbonatada epeírica (Formaciones Imón e Isábena) del Triásico superior del Noreste de la Península Ibérica. Acta Geol. Hisp. 37, 299-328.

Aurell, M., Meléndez, G., Bádenas, B., 2002. East Iberian basins. In: Gibbons, W., Moreno, T. (Eds.), The Geology of Spain. Geological Society, London, pp. 223-229.

Aurell, M., Robles, S., Bádenas, B., Rosales, I., Quesada, S., Meléndez, G., García-Ramos, J.C., 2003. Transgressive-regressive cycles and Jurassic palaeogeography of northeast Iberia. Sediment. Geol. 162, 239-271.

Barrón, E., Goy, A., 1994. Caracterización palinológica del tránsito Triásico/Jurásico en la región de Sigqenza (Guadalajara, Españ a). Proc. III Col. Estrat. Paleog. Pérmico y Triásico España, Cuenca, Spain, 13.

Barrón, E., Gómez, J.J., Goy, A., 2001. Dataciones con palinomorfos en los materiales del tránsito Triásico-Jurásico de Poza de la Sal. Publ. Semin. Paleontol. Zaragoza 5, 46-55. 
Bassoullet, J.P., Elmi, S., Poisson, A., Ricou, L.E., Cecca, F., Bellion, Y., Guiraud, R., Baudin, F., 1993. Mid Toarcian (184 to 182 Ma). In: Decourt, J., Ricou, L.E., Vrielynck, B. (Eds.), Atlas Tethys; Palaeoenvironmental Maps. BEICIP-FRANLAB. RueilMailmaison, France, pp. 63-80.

Bordonaba, A.P., Aurell, M., 2001. El Pliensbachiense de la Rama Aragonesa de la Cordillera Ibérica: análisis secuencial. Geotemas 3, 89-92.

Bordonaba, A.P., Aurell, M., 2002. El Pliensbachiense de la Rama Aragonesa de la Cordillera Ibérica: análisis de facies y establecimiento de secuencias. J. Iber. Geol. 28, 31-44.

Bradshaw, M.J., Cope, J.C.W., Crips, D.W., Donovan, D.T., Howart, M.K., Rawson, P.F., Wimbledon, W.A., 1992. Jurassic. In: Cope, J.C.W., Ingram, J.K., Rawson, P.F. (Eds.), Atlas of Palaeogeography and Lithofacies, vol. 13. Mem. Geol. Soc., London, pp. 1-109.

Braga, J.C., Comas-Rengifo, M.J., Goy, A., Rivas, P., Yébenes, A., 1988. El Lías inferior y medio en la zona central de la Cuenca Vasco-Cantábrica (Camino, Santander). Ciencias de la Tierra 11, $17-45$.

Capote, R., Díaz, M., Gabaldón, V., Gómez, J.J., Sánchez de la Torre, L., Ruiz, P., Rosell, J., Sopeña, A., Yébenes, A., 1982. Evolución sedimentológica y tectónica del Ciclo Alpino en el tercio noroccidental de la Rama Castellana de la Cordillera Ibérica. Temas Geol.-Min. 290 pp.

Castillo-Herrador, F., 1974. Le Trias évaporitique des basins de la Vallée de l'Èbre et de Cuenca. Bull. Soc. Géol. Fr. 16, 666-675.

Catuneanu, O., Willis, A.J., Miall, A., 1998. Temporal significance of sequence boundaries. Sediment. Geol. 121, 157-178.

Comas-Rengifo, M.J., 1985. El Pliensbachiense de la Cordillera Ibérica. Colección Tesis Doctorales, 19/85. Univ. Complutense Madrid, Spain. 594 pp.

Comas-Rengifo, M.J., Gómez, J.J., Goy, A., Arias, C.F., Bernad, J., García Joral, F., Herrero, C., Martínez, G., Perilli, N., 1996. The Toarcian in the Rambla del Salto (Sierra Palomera) section. 1st Toarcian and 4th Aalenian working groups meeting. International subcomission on Jurassic stratigraphy. Field Trip Iberian Range Guide Book, pp. 27-48.

Comas-Rengifo, M.J., Gómez, J.J., Goy, A., Herrero, C., Perilli, N., Rodrigo, A., 1998. El Sinemuriense y el Pliensbachiense en la secció n de Alfara. Cordillera Costero-Catalana (Tarragona). Cuad. Geol. Iber. 24, 173-184.

Comas-Rengifo, M.J., Gómez, J.J., Goy, A., Herrero, C., Perilli, N., Rodrigo, A., 1999. El Jurásico Inferior en la sección de Almonacid de la Cuba (Sector central de la Cordillera Ibérica, Zaragoza, España). Cuad. Geol. Iber. 25, 27-57.

Cresta, S., Goy, A., Ureta, S., Arias, C., Barrón, E., Bernad, J., Canales, M.L., García-Joral, F., García-Romero, E., Gialanella, P.R., Gó mez, J.J., González, J.A., Herrero, C., Martínez, G., Osete, M.L., Perilli, N., Villalaín, J.J., 2001. The Global Boundary Stratotype Section and Point (GSSP) of the Toarcian-Aalenian Boundary (Lower-Middle Jurassic). Episodes 24, 166-175.

Decourt, J., Ricou, L.E., Vrielynck, B. (Eds.), 1993. Atlas Tethys Palaeoenvironmental Maps, BEICIP-FRANLAB. Gauthier-Vollars, Paris. 260 pp., 14 maps. de Graciansky, P.C., Jacquin, T., Hesselbo, S.P., 1998. The Ligurian Cycle: an overview of Lower Jurassic 2nd-order transgressive/regressive facies cycles in Western Europe. In: de Graciansky, P.C., Hardenbol, J., Jacquin, T., Vail, P. (Eds.), Mesozoic and Cenozoic Sequence Stratigraphy of European Basins, Spec. Publ.-Soc. Sediment. Geol., vol. 60. SEPM, Tulsa, OK, pp. 467-479.

Duarte, L.V., Krautter, M., Soares, A.F., 2001. Bioconstructions à spongiaires siliceux dans le Lias terminal du Bassin lusitanien (Portugal): stratigraphie, sédimentologie et signification paléogéographique. Bull. Soc. Géol. Fr. 172, 637-646.

Fendler, E.E., 1979. Indications of emergence and terrigenous processes in the Jurassic of the Hesperian Range, Spain. Neues Jahrb. Geol. Pal7ontol., Monatsh. 12, 705-722.

Fernández-López, S., 1985. El Bajociense de la Cordillera Ibérica. $\mathrm{PhD}$ thesis, Univ. Complutense Madrid, Spain.

Fernández-López, S., 1991. Taphonomical concepts for a theoretical biochronology. Rev. Esp. Paleontol. 6, 37-49.

Fernández-López, S., 1997. Ammonites, taphonomic cycles and stratigraphic cycles in carbonate epicontinental platforms. Cuad. Geol. Iber. 23, 95-136.

Fernández-Ló pez, S., Gó mez, J.J., 1990a. Evolution tectonosedimentaire et genèse des associations d'Ammonites dans le Secteur Central du bassin Ibérique (Espagne) pendant l'Aalenien. Cah. Univ. Cathol. Lyon, Sér. Sci. 4, 39-52.

Fernández-López, S., Gómez, J.J., 1990b. Facies aalenienses y bajocienses, con evidencias de emersión y carstificación, en el sector central de la Cuenca Ibérica. Implicaciones paleogeográficas. Cuad. Geol. Iber. 14, 67-111.

Fernández-López, S., Gómez, J.J., Goy, A., 1985. Le Dogger de Caudiel. Sédimentologie des carbonates développés sur un bmonticuleQ de matériaux volcaniques. Strata 2, 101-117.

Fernández-Ló pez, S., García Joral, F., Gó mez, J.J., Henriques, M.H.P., Martínez, G., 1998a. La diferenciación paleogeográfica de la Cuenca Catalana al pricipio del Jurásico Medio. Rev. Soc. Geol. Esp. 11, 3-22.

Fernández-López, S., Aurell, M., García Joral, F., Gómez, J.J., Henriques, M.H.P., Martínez, G., Meléndez, G., Suárez-Vega, L.C., 1998b. La Plataforma de Tortosa (Cuenca catalana) durante el Jurásico Medio: unidades litoestratigráficas, paleogeografía y ciclos ambientales. Cuad. Geol. Iber. 24, 185-221.

Gautier, F., 1968. Sur l'existence et l'âge d'un paléovolcanisme dans le Jurasique Sud-aragonais (Espagne). C.R. Somm. Seances Soc. Geol. Fr. 3, 74-75.

Gautier, F., 1974. Hoja geológica no. 614 (Manzanera) escala 1: 50.000 (Segunda Serie, MAGNA). IGME, Madrid, Spain, $24 \mathrm{pp}$.

Gianolla, P., Jacquin, T., 1998. Triassic sequences stratigraphic framework of western European basins. In: de Graciansky, P.C., Hardenbol, J., Jacquin, T., Vail, P. (Eds.), Mesozoic and Cenozoic Sequence Stratigraphy of European Basins, Spec. Publ.-Soc. Sediment. Geol., vol. 60. SEPM, Tulsa, OK, pp. 643-650.

Gó mez, J.J., 1979. El Jurásico en facies carbonatadas del Sector Levantino de la Cordillera Ibérica. Seminar. Estratigr. Serie Monografías, vol. 4. Univ. Complutense Madrid, Spain. 683 pp. 
Gó mez, J.J., 1985a. Sedimentología y paleogeografía del Jurásico en la hoja geoló gica no. 55 (7-7), Llíria, del Mapa Geoló gico de España a escala de 1:200.000. IGME, Madrid, Spain, pp. 37-60.

Gómez, J.J., 1985b. Sedimentología y paleogeografía del Jurásico Inferior y Medio en la hoja geológica no. 47 (7-6), Teruel, del Mapa Geoló gico de Españ a a escala de 1:200.000. IGME, Madrid, Spain, pp. 47-72.

Gómez, J.J., 1991. Sedimentología y paleogeografía del Jurásico en la hoja geológica no. 40 (7-5) de Daroca del Mapa Geológico de España a escala de 1:200.000. ITGE, Madrid, Spain, pp. 31-82.

Gómez, J.J., Fernández-López, S., 1994. Condensation processes in shallow platforms. Sediment. Geol. 92, 147-159.

Gómez, J.J., Fernández-López, S.R., 2004. Jurásico Medio de las cordilleras Ibérica y Costero-Catalana. In: Vera, J.A. (Ed.), Geología de España. SGE-IGME, Madrid, pp. 500-503.

Gó mez, J.J., Goy, A., 1979. Las unidades litoestratigráficas del Jurásico medio y superior en facies carbonatadas del Sector Levantino de la Cordillera Ibérica. Estud. Geol. 35, 17-57.

Gó mez, J.J., Goy, A., 1981. Evolución lateral de las unidades litoestratigráficas en facies carbonatadas de la Cordillera Ibérica. Cuad. Geol.-Univ. Granada 10, 83-93.

Gómez, J.J., Goy, A., 1997. El Jurásico de la Cordillera Ibérica: estratigrafía secuencial y paleogeografía. Proc. IV Congr. del Jurásico de España, Alcañiz, Spain, 15-16.

Gó mez, J.J., Goy, A., 1998. Las unidades litoestratigráficas del tránsito Triásico-Jurásico en la región de Lécera (Zaragoza). Geogaceta 23, 63-66.

Gó mez, J.J., Goy, A., 1999. Las unidades carbonatadas y evaporíticas del tránsito Triásico-Jurásico en la región de Lécera (Zaragoza). Cuad. Geol. Iber. 25, 15-25.

Gómez, J.J., Goy, A., 2000. Sequential analysis of the Toarcian in the Northern and Central-Eastern part of the Iberian subplate (Spain). In: Hall, R.L., Smith, P.L. (Eds.), Advances In Jurassic Research, GeoResearch Forum, vol. 6, pp. 301-309 Switzerland.

Gó mez, J.J., Goy, A., 2004. Jurásico Inferior de las cordilleras Ibérica y Costero-Catalana. In: Vera, J.A. (Ed.), Geología de España. SGE-IGME, Madrid, pp. 495-500.

Gó mez, J.J., Trell, A., Pérez, P., 1976. Presencia y edad de vulcanitas en el Jurásico del Norte de Valencia (Cordillera Ibérica, España). Acta Geol. Hisp. 11, 1-7.

Gó mez, J.J., Comas-Rengifo, M.J., Goy, A., 2003. Las unidades litoestratigráficas del Jurásico Inferior de las cordilleras Ibérica y Costeras Catalanas. Rev. Soc. Geol. Esp. 16, 227-237.

Goy, A., 1974. El Lias de la mitad norte de la Rama Castellana de la Cordillera Ibérica. PhD thesis. Univ. Complutense Madrid, Spain (Abstract in Publ. Dep. Paleontol. UCM 14, 1-35).

Goy, A., Márquez-Aliaga, A., 1998. Bivalvos del Triásico Superior de la Formación Imón (Cordillera Ibérica, España). Bol. R. Soc. Esp. Hist. Nat. (Sec. Geol.) 94, 77-91.

Goy, A., Gómez, J.J., Yébenes, A., 1976. El Jurásico de la Rama Castellana de la Cordillera Ibérica (Mitad Norte). Unidades litoestratigráficas. Estud. Geol. 32, 391-423.

Goy, A., Comas-Rengifo, M.J., Arias, C., García Joral, F., Gómez, J.J., Herrero, C., Martínez, G., Rodrigo, A., 1997. El Tránsito
Pliensbachiense/Toarciense en el sector central de la Rama Aragonesa de la Cordillera Ibérica (España). Cah. Univ. Cathol. Lyon 10, 159-179.

Grandstein, F.M., Agterberg, F.P., Ogg, J.G., Hardenbol, J., Van Veen, P., Thierry, J., Huang, Z., 1995. A Triassic, Jurassic and Cretaceous time scale. In: Berggren, W.A., Kent, D.V., Aubry, M.P., Hardenbol, J. (Eds.), Geochronology, Time Scales and Global Stratigraphic Correlation, Spec. Publ., vol. 54. SEPM, Tulsa, OK, pp. 95-126.

Guillocheau, F., 1995. Nature, rank and origin of Phanerozoic sedimentary cycles. C. R. Acad. Sci., Paris 320, 1141-1157.

Hallam, A., 2001. A review of the broad pattern of Jurassic sealevel changes and their possible causes in the light of current knowledge. Palaeogeogr. Palaeoclimatol. Palaeoecol. 167, 23-37.

Haq, B.L., Hardenbol, J., Vail, P., 1988. Mesozoic and Cenozoic Chronostratigraphy and Eustatic Cycles. In: Wilgus, C.K., Hastings, B.S., Kendall, C.G.St.C., Posamentier, H.W., Ross, C.A., Van Wagoner, J.C. (Eds.), Sea Level Changes: An Integrated Approach, Spec. Publ., vol. 42. SEPM, Tulsa, OK, pp. 71-108.

Hardenbol, J., Thierry, J., Farley, M.B., Jacquin, T., de Graciansky, P.C., Vail, P.R., 1998. Mesozoic and Cenozoic sequence chronostratigraphic framework of European basins. In: de Graciansky, P.C., Hardenbol, J., Jacquin, T., Vail, P. (Eds.), Mesozoic and Cenozoic Sequence Stratigraphy of European Basins, Spec. Publ.-Soc. Sediment. Geol., vol. 60. SEPM, Tulsa, OK, pp. 3-13.

Harding, T.P., Lowell, D., 1979. Structural styles, their platetectonic habitats, and hydrocarbon traps in petroleum provinces. AAPG Bull. 63, 1016-1058.

Harris, P.J., Little, C.T.S., 1999. The early Toarcian (Early Jurassic) and the Cenomanian-Turonian (Late Cretaceous) mass extinctions: similarities and contrasts. Palaeogeogr. Palaeoclimatol. Palaeoecol. 154, 39-66.

Hesselbo, S.P., Jenkins, H.C., 1993. A comparison of the Hettangian to Bajocian successions of Dorset and Yorkshire. In: Taylor, P.D. (Ed.), Field Geology of the British Jurassic. Geol. Soc, London, pp. 105-150.

Jacquin, T., de Graciansky, P.C., 1998. Major transgressive/ regressive cycles: the stratigraphic signature of European basin development. In: de Graciansky, P.C., Hardenbol, J., Jacquin, T., Vail, P. (Eds.), Mesozoic and Cenozoic Sequence Stratigraphy of European Basins, Spec. Publ.-Soc. Sediment. Geol., vol. 60. SEPM, Tulsa, OK, pp. 15-29.

Jenkyns, H.C., 1988. The early Toarcian (Jurassic) anoxic event: stratigraphic, sedimentary and geochemical evidence. Am. J. Sci. 288, 101-151.

Jenkyns, H.C., Clayton, C.J., 1986. Black shales and carbon isotopes in pelagic sediments from the Tethyan lower jurassic. Sedimentology 33, 87-106.

Jenkyns, H.C., Clayton, C.J., 1997. Lower Jurassic epicontinetal carbonates and mudstones from England and Wales: chemostratigrahic signals and the early Toarcian anoxic event. Sedimentology 44, 687-706.

Jiménez, A.P., Jiménez de Cisneros, C., Rivas, P., Vera, J.A., 1996. The early Toarcian anoxic event in the westernmost Tethys 
(Subbetic): paleogeographic and paleobiogeographic significance. J. Geol. 104, 399-416.

Jurado, M.J., 1990. El Triásico y el Liásico basal evaporíticos del subsuelo de la cuenca del Ebro. In: Ortí Cabo, F., Salvany Durán, J.M. (Eds.), Formaciones evaporíticas de la Cuenca del Ebro y cadenas periféricas, y de la zona de Levante. Nuevas aportaciones y guía de superficie, Spain, pp. 21-28.

Márquez, L., Calvet, F., Arnal, I., Trifonova, E., 1994. Asociación de foraminíferos en la Formación Isábena, Triásico superior Sudpirenaico (España). Bol. R. Soc. Esp. Hist. Nat. (Sec. Geol.) 89, 189-197.

Martínez González, R.M., Lago, M., Valenzuela Ríos, J.I., Vaquer, R., Salas, R., 1996. El magamatismo alcalino jurásico del sector SE de la Cadena Ibérica: composición y estructura. Geogaceta 20, 1687-1690.

Martínez González, R.M., Lago San José, M., Valenzuela Ríos, J.I., Vaquer Navarro, R., Salas, R., Dumitrescu, R., 1997. El volcanismo Triásico y Jurásico del sector SE de la Cadena Ibérica y sus relaciones con los estadios de rift mesozoicos. Bol. Geol. Min. 108, 367-376.

Morillo Velarde, M.J., Meléndez Hevia, F., 1979. El Jurásico de bLa AlcarriaQ-bLa ManchaQ. Cuad. Geol.-Univ. Granada 10, 149-166.

Mouterde, R., 1971. Un coupe du Lias à Obon aux confins des provinces de Teruel et de Saragosse. Cuad. Geol. Iber. 2, 345-354.

Ortí, F., Sanfeliú, T., 1971. Estudio del vulcanismo Jurásico de Caudiel (Castellón) en relación con los procesos de lateritización, condensación y silificación de la serie calcárea. Inst. Inv. Geol. Dip. Prov. Univ. Barcelona 26, 21-34.

Ortí, F., Vaquer, R., 1980. Volcanismo Jurásico del sector valenciano de la Cordillera Ibérica. Distribució n y trama estructural. Acta Geol. Hisp. 15, 127-130.

Pérez-López, A., Solé de Porta, N., Ortí, F., 1996. Facies carbonatoevaporíticas del Trías Superior y tránsito al Lías en el Levante español: nuevas precisiones estratigráficas. Cuad. Geol. Iber. 20, 245-269.

Rios, L.M., Beltrán, F.J., Lanaja, J.M., 1981. Hoja geológica no. 467 (Muniesa), escala 1:50.000 (Segunda Serie, MAGNA), IGME, Madrid, Spain. 25 pp.

Salas, R., Casas, A., 1993. Mesozoic extensional tectonics, stratigraphy and crustal evolution during the Alpine cycle of the eastern Iberian Basin. Tectonophysics 228, 33-55.

Salas, R., Guimerá, J., Mas, R., Martín-Closas, C., Meléndez, A., Alonso, A., 2001. Evolution of the Mesozoic Central Iberian Rift System and its Cainozoic inversion (Iberian Chain). In: Ziegler, P.A., Cavazza, W., Robertson, A.H.F., Crasquin-Soleau, S. (Eds.), Peri-Tethys Memoir 6: Peri-Tethyan Rift/Wrench Basins and Passive Margins, Mém. Mus. Natl. Hist. Nat., 186, pp. 145-185 Paris, France.
Sequeiros, L., Colera, I., Valenzuela, R., Sánchez, I., 1978. Bioestratigrafía del Jurásico (Lias y Dogger) en el sector Belchite-Almonacid de la Cuba (prov. de Zaragoza, Cordillera Ibérica). Estud. Geol. 34, 293-298.

Stampfli, G.M., Mosar, J., Favre, P., Pillevuit, A., Vannay, J.C., 2001. Permo-Mesozoic evolution of the Western Tethys realm: the Neo-Tethys-East Mediterranean basin connection. In: Ziegler, P.A., Cavazza, W., Robertson, A.H.F., CrasquinSoleau, S. (Eds.), Peri-Tethys Memoir 6: Peri-Tethyan Rift/ Wrench Basins and Passive Margins, Mém. Mus. Natl. Hist. Nat., vol. 186, pp. 51-108. Paris, France.

Suárez Vega, L.C., 1974. Estratigrafía del Jurásico en Asturias. Cuad. Geol. Iber. 3, 1-369.

Thierry, J., 2000a. 7.-Late Sinemurian (193-191 Ma). In: Decourt, J., Gaetani, M., Vrielynck, B., Barrier, E., Biju-Dubal, B., Brunet, M.F., Cadet, J.P., Crasquin, S., Sandulescu, M. (Eds.), Peri-Tethys Atlas. Paleogeographical Maps. Commission for the Geologic Map of the World, Paris, France, pp. 49-59.

Thierry, J., 2000b. 8.-Middle Toarcian (180-178 Ma). In: Decourt, J., Gaetani, M., Vrielynck, B., Barrier, E., Biju-Dubal, B., Brunet, M.F., Cadet, J.P., Crasquin, S., Sandulescu, M. (Eds.), Peri-Tethys Atlas. Paleogeographical Maps. Commission for the Geologic Map of the World, Paris, France, pp. $61-70$.

Ureta, S., 1985. Bioestratigrafía y Paleontología (Ammonitina) del Aaleniense en el Sector Noroccidental de la Cordillera Ibérica. Colección Tesis Doctorales 158/85. Univ. Complutense Madrid, Spain, 452 pp.

Vera, J.A., 2001. Evolution of the South Iberian continental margin. In: Ziegler, P.A., Cavazza, W., Robertson, A.H.F., CrasquinSoleau, S. (Eds.), Peri-Tethys Memoir 6: Peri-Tethyan Rift/ Wrench Basins and Passive Margins, Mém. Mus. Natl. Hist. Nat., vol. 186, pp. 51-108 Paris, France.

Yébenes, A., Comas-Rengifo, M.J., Gómez, J.J., Goy, A., 1988. Unidades tectosedimentarias en el Lías de la Cordillera Ibérica. Proc. III Coloquio de Estratigrafía Paleogeografía del Jurásico de España. Logroño, Spain, 108-109.

Ziegler, P.A., 1982. Geological Atlas of Western and Central Europe. Shell International Petroleum Maatschappij B.V. 130 pp., 40 encl.

Ziegler, P.A., 1990. Geological Atlas of Western and Central Europe (2nd edition). Shell Internationale Petroleum Maatschappij. Bath Geological Society Publication House. 239 pp., 56 encl.

Ziegler, P.A., Cloetingh, S., Giraud, R., Stampfli, G.M., 2001. PeriTethyan platforms: constraints on dynamics of rifting and basin inversion. In: Ziegler, P.A., Cavazza, W., Robertson, A.H.F., Crasquin-Soleau, S. (Eds.), Peri-Tethys Memoir 6: Peri-Tethyan Rift/Wrench Basins and Passive Margins, Mém. Mus. Natl. Hist. Nat., vol. 186, pp. 9-49 Paris, France. 